\title{
Jurisdição Administrativa na França
}

\author{
Octavio de Barros Marques
}

$\mathrm{O}$

traço mais importante do sistema administrativo francês, o que lhe dá o cunho original, é a existência de uma jurisdição administrativa ao lado da jurisdição judiciária, ambas autônomas mas separada aquela da Administração ativa.

A primeira vista, temos a impressão que a justificativa para a dualidade de jurisdições teria sido de ordem técnica. Tratan do-se de ramo nôvo e especializado da ciência juridica, a aplicação do Direito Administrativo ensejaria a criação de uma ordem de tribunais especiais. Contudo, se o problema se apresenta nesses têrmos atualmente, nem sempre assim foi, como veremos a seguir.

Os primórdios da jurisdição administrativa na França remontam aos primeiros anos da Revolução. Receosos de que a ação administrativa fôsse obstada pelos tribunais, tal como já ocorrera no tempo da monarquia absoluta, os revolucionários logo de início, invocando o princípio da separação dos podêres, impediram fôssem os administradores, por seus atos ou funções, cerceados pelos tribunais judiciários. A célebre lei de 16-24 de agôsto de 1790 é sintomática quando estipula: "As funções judic'árias são e permanecerão sempre separadas das funções administrativas. Os Juizes não poderão, sob pena de crime, perturbar de modo algum as operações dos corpos administrativos, nem mandar citar os administradores em razão de suas funções." Estava, dêsse modo. salvaguardada a ação administrativa do nôvo regime e, sem maiores escrúpulos, os revolucionários confiam à própria Administração a tarefa de julqar o contencioso administrativo, isto é, os litígios que a atividade administrativa poderia gerar. E o sistema chamado "administrador juiz. Adotou-se, pois, solução que hoje se nos afigura paradoxal: confiar parte da funcão jurisdicional à Administração ativa, em nome da separacâo dos podêres. Durante todo o periodo revolucionário, vimos a Administração julqar os litígios em que ela era parte, isto é, julgar em causa própria. Tal sistema parecia absurdo. Era pre- 
ciso separar a Administração da jurisdição. A essa idéia prătıca cabia dar um fundamento constitucional. Assim, ainda em nome da separação dos podêres, foi criada uma ordem de tribunais distintos, ao mesmo tempo, do poder judiciário e do poder administrativo. Inspirada por receios politicos e arrimada em argumentos de caráter constitucional, tal é a origem histórica da jurisdição administrativa francesa. Todavia, a preocupação antijudiciária do inicio permaneceu intensa ainda por muito tempo. Por isso a solução de uma jurisdição administrativa, com total independência da Administração ativa, só foi obtida progressivamente, como passaremos a examinar.

A formação da jurisdição administrativa, na França, se fêz por atapas. A primeira foi a criação, no ano VIII da Revolução (1799), sob o Consulado, dos grandes tribunais administrativos: - Conselho do Estado (Constituição do ano VIII) e os Conselhos de "Préfecture" (1) (lei de 28 "pluviôse" do ano VIII).

O Conselho de Estado, a principio, não tinha funções de julgador. Tratava-se de órgão, como o próprio nome indica, incumbido apenas de opinar não só a respeito de assuntos litigiosos (contencioso), mas também, como ainda ocorre atualmente, sôbre matéria administrativa. Êle não decidia. Limitava-se a propor a solução ao Primeiro Cônsul. A Administração continuava, pois, como juiz. É o que se chama a "justice retenue", a qual durou três quartos de século. Contudo, já o progresso fôra enorme, se levarmos em conta que o Chefe de Estado não discrepava do parecer do Conselho. A lei de 24 de maio de 1872 acabou por consagrar em texto normativo, êsse avanço, estabelecendo que o Conselho de Estado, ao examinar o contencioso, julgaria êle próprio os litígios, sem a intervenção do Chefe de Estado. É a chamada "justice déléguée." A partir de 1872 , portanto, a jurisclição administrativa francesa era completamente autônoma. Havia, porćm, ainda, alguns resquícios da teoria da "administração-juiz", os quais, em breve, seriam abandonados. Até o fim do século XIX, afirmava-se que a legislação do ano VIII não havia suprimido o sistema da "administração-juiz." Eram os ministros, dizia-se então, cada um dentro dos assuntos que the competiam, os iuizes administrativos de direito comum. Os textos do ano VIII haviam apenas superposto, mas não substituido, à iurisdição dos ministros a jurisdição do Conselho de Estado que funcionava como instância superior. Em conseqüência, afora os casos em que um texto formal dava, sôbre determinado ponto,

1. Préfecture. Mantivemos a palavra em francês por não comportar tradução adequada em nossa lingua. "Préfecture" é a circunscrição administrativa de um "prefeito", correspondente a um "departamento", e não a um municipio, como entre nós. 
competência a um tribunal administrativo, não havia outra alternativa para os administrados senão se dirigirem ao "ministro-juiz", cabendo de sua decisão recurso ao Consélho de Estado. A teoria do "ministro-juiz" era aceita pela doutrina e pela jurisprudência. Ela restringia a reforma do ano VIII, que criara os tribunais administrativos (Conselho de Estado e Conselhos de "Préfecture") fazendo dêles juízes apenas em grau de recurso. Enquanto isso, o juiz administrativo continuava a ser a Administração ativa. Foi sòmente pela evolução da jurisprudência, definitıvamente marcada pela decisão do Conselho de Estado, em 1889, no caso "Cadot", que foi abandonada a teoria do "ministro-juiz." Assim, ficava confirmada e unificada a jurisdição administrativa em favor do Conselho de Estado que se tornou o juiz administrativo de direito comum.

Com o correr do tempo, verificou-se que a razão politica que levara a Revolução a impedir o exame do contencioso administrativo, por parte do poder judiciário, desaparecera. Atualmente, a unificação das jurisdições administrativa e judiciária teria objetivos práticos, dos quais o mais importante seria o de evitar os corflitos que a dualidade de jurisdições provoca, conflitos êsses dirimidos aliás pelo Tribunal de Conflitos. Contudo, no presente, outra razão, de não pouca valia, justifica a continuidade da jurisdição dupla. Essa razão diz respeito ao caráter especial e ao particularismo do direito administrativo, cuja aplicação explica a existência de uma jurisdição especializada. E não só a aplicação mas também a elaboração dêsse direito que, na França, é nit:damente pretoriano. Assim a razão de ordem política que ensejou a criação de jurisdição especial, para examinar os litígios administrativos (contencioso), cede lugar hoje a motivo de caráter técnico e prático.

Como vimos no início, os tribunais que constituem essa jurisdição especial foram criados no ano VIII da Revolução (1799), dição especial foram criados no ano no Consulado. O Conselho de Estado e os
por Napoleão, já no Consecture",
Tribunais Administrativos, antigos Conselhos de "Prétecture são os elementos essenciais do sistema.

Todos os tribunais administrativos dependem, direta ou indiretamente, do contrôle do Conselho de Estado. Esse órgão é, ao mesmo tempo, julgador e conselheiro. Até 1953, o Conselho foi o juiz de direito comum em matéria administrativa. Isto quer dizer que o Conselho era competente para tôdas as demandas do contencioso administrativo que a lei não havia atribuido a outro tribunal. Com o advento de decreto de 30 de setembro de 1953, os antigos Conselhos de "Préfecture" formsformansfor. mados em Tribunais Administrativos. Essa transformação objetivou, sobretudo, ampliar a competência dos antigos Conselhos 
e, em conseqüência, restringir a do Conselho de Estado, ao qual ficaram subordinados os Tribunais Administrativos. De suas decisões cabe recurso para o Conselho de Estado que funciona assim como instância superior. Contudo, em certas matérias, o Conselho decide em primeira e última instância. É o caso do "recurso $\left({ }^{2}\right)$ por excesso de poder" de que nos ocuparemos adiante. Ccmo vimos, o Conselho de Estado, a principio, era um órgão simplesmente consultivo. Mais tarde é que passou a exercer funções de julgador, mas sempre conservando suas atribuições consultivas. A "ordonnance" $\left(^{3}\right)$ de 1945 e os decretos de 30 de julho de 1963 confirmaram essas atribuições. O Conselho continua, por exemplo, a ser obrigatòriamente ouvido sôbre os projetos de lei. Também-é chamado obrigatòriamente a opinar sôbre as "ordonnances" e sôbre os regulamentos da administração pública.

Sediado em Paris, o Conselho de Estado exerce sua jurisdição em todo o território francês. Já a dos Tribunais Administrativos se circunscreve a certas porções do território, abrangendo a jurisdição de cada Tribunal Administrativo apenas alguns "departamentos." ( $\left.{ }^{4}\right)$ Há cêrca de 30 Tribunais Administrativos, na França.

Passemos agora à análise dos principais recursos cabiveis perante a justiça administrativa. É óbvio que trataremos dos recursos contenciosos que são os que nos interessam, deixando de lado os recursos administrativos, graciosos ou hierárquicos, de resto, bastante conhecidos em nossa sistemática administrativa. Os recursos contenciosos mais importantes, na França, são o recurso por excesso de poder (objetivo) e o recurso de plena jurisdição, também chamado de indenização (subjetivo). No primeiro, a questão a ser apreciada pelo juiz é a da legalidade de um ato administrativo. O requerente pleiteia a anulação do ato, um decreto, por exemplo, por o entender ilegal. Por isso é que se diz que o recurso não é um processo entre partes, mas um processo feito a um ato. O próprio nome do recurso advém do

2. Recurso. Nem sempre a palavra é empregada no texto na acepção usual. "Recurso", no caso, por exemplo, de excesso de poder, corresponde ao nosso vocábulo "ação."

3. Ordonnance. Texto no"mativo, com fôrça de lei, que emana de um govêrno provisório. Espécie de decreto-lei.

4. Departamento. Cada uma das divisões principais do território francês, administrada por um "prefeito" (préfet), o qual é assistido por um Conselho Geral, órgão eletivo. A França foi dividida em departamentos, pela Revolução. Ao todo são noventa os departamentos que passaram a substituir as antigas provincias, menos numerosas aliás. Contudo, a França é um Estado unitário. 
caráter da pretensão. Trata se de anular ato para cuja consecução a autoridade agiu com excesso de poder. É, pois, um recurso do contencioso dito "objet.vo", nesse sentido de que êle levanta uma questao de puro aireito objetıvo, a da violação de uma regra de direito objetivo. Se anulado o ato a medida aproveita a todos. Já no chamado recurso de plena jurisaição ou de indenização se discute situação juridica ind.vidual a qual é contestada ao requerente pela Administração. Nesse caso, aliás, faz-se necessário a decisão prévia (décision préalable) da Administração, sem a qual o admin strado não poderá dirigir-se ao juiz administrativo. O requerente pleiteia algo da Administração, uma prestação qualquer. Por êsse motivo é também denominado recurso de indenização, uma vez que, ao decidir, a autoridade não se 1 mita a anular ato da Administração. Condena-a também, obrigando-a a uma indenização ou qualquer outra prestação.

É recurso que aproveita só ao litigante. Daí fazer parte do contencioso dito "subjetivo".

Para que o recurso por excesso de poder seja admitido é necessário o preenchimento de quatro condições que devem ser observadas simultâneamente. São elas a saber: a natureza do ato, a qualidade da parte, a observância da forma processual e a ausênc a de recurso paralelo. Vamos examinar, uma a uma, essas condições. 1" Condição: Natureza do ato - São suscetíveis de recurso apenas os atos administrativos que contêm decisão executiva. $\mathrm{O}$ ato, objeto do recurso, tem de ser administrativo. A jurisprudência reconhece êsse caráter nos atos que dizem respeito às relações de direito público, e não de direito privado, o que pressupõe que o autor do ato pertença aos quadros da Administração francesa, ficando, assim, eliminadas "de plano" as auturidades judiciais e legislativas. Além disso, o ato deve reportar-se a atribuções administrativas, o que implica em afastar os atos que decorrem de atribuições não administrativas, tais como os atos de govêrno. Isto pôsto, cabe agora dizer que o ato deve conter, como já esclarecemos, uma decisão executória, isto ê, deve ser ato unilateral que exprima ùnicamente a vontade da Administração, excluidos, assim, os atos de natureza contratual. Deve ainda êsse ato produzir efe to executório quanto aos administrados, o que elimina os atos administrativos meramente preparatórios de uma decisão futura. 2a Condição: Qualifade da parte - É necescáro que o autor do recurso tenha um interêsse direto e pessoal, ferido. Não se exiqe direito violado, uma vez que não se trata do contencioso de plena jurisdição. Basta, portanto, o interêsse ferido. 3a Condicão: A forma processual e o nrazo - Consiste cla na redação de requerimento em papel timbrado, não havendo necessidade de advogado. Ao requerimento deve 
ser anexada cópia do ato impugnado. Quanto ao prazo, é de dois meses a partir da publicação do ato. 4" Condição: Ausência de recurso paralelo - Essa última condição faz lembrar que, sendo o recurso por excesso de poder um remédio excepcional, nâo teria êle razâo de ser se o requerente já houvesse pleiteado, por outra via contenciosa, a satisfação de seu interêsse. Dado, porém, o alargamento do recurso por excesso de poder, esta última condição tem perdido muito de sua importância. Quatro também são as causas que dão cabimento ao recurso por excesso de poder: a incompetência, o vício de forma, o desvio de poder e a violação da lei. É necessário à licitude do ato administrativo que êle emane não apenas de um agente da Administração mas daquele agente a quem a lei concedeu a faculdade de agir em nome do Estado. A incompetência permite anular o ato que uma autoridade praticou no lugar de outra. O vicio de forma resulta da omissão total ou parcial de formalidade prevista em lei ou regulamento, para a concretização do ato. O desvio de poder diz respeito à moralidade administrativa. Ele tem lugar quando o agente respeitou a letra da lei, isto é, era competente e observou a forma prescrita, porém com outro fim que não aquêle para o qual êle foi investido. Por exemplo: a autoridade nolicial, no uso de suas atribuições, manda fechar um bar. Se êle adotou a medida para salvaguardar a tranqüilidade pública, sua decisão é correta. Contudo, se êle baixa o ato para satisfazer vingança de ordem pessoal, houve o desvio de poder, o qual poderá dar lugar à anulação. A violação da lei. - Não há dúvida de que a incompetência e a inobservância da forma constituēm violação que dizem respeito ao aspecto legal do ato. Contudo, nesse caso, trata-se de legalidade extrinseca, envolvendo, pois, os aspectos exteriores do ato. No entanto, entende-se por violação da lei "stricto sensu" aquela que conduz a verificar se o ato, nas suas disposições de fundo, não viola uma regra legal. A jurisprudência, na França, entende essa violação da lei de maneira muito ampla. A "legalidade" compreende não sòmente - que é prescrito em lei pròpriamente dita, votada pelo Parlamento, mas também tudo o que tem valor de regra geral e obrigatória, em razão dos regulamentos, do costume ou da jurisprudência. Essa noção de "legalidade" foi de tal modo alargada que chega até a envolver os chamados princípios gerais de direito. Tendo em vista, pois, essa concepsão tão ampla, é perquirida a falsa invocação da regra ou êrro de direito, o qual se configura quando a decisão atribui a um texto o que êle não diz; e a falsa aplicação da regra ou êrro de fato, o qual consiste em aplicar um texto a uma situação que a êle não se ajusta.

O recurso por excesso de poder, o mais importante do contencioso administrativo, é uma criação original ao direito admi- 
vistrativo francês que permite aos administrados seja apreciada, pelo Conselho de Estado ou Tribunal Administrativo, a regularidade das decisões administrativas.

Façamos agora um rápido bosquejo do que têm sido os remédios judiciais contra o abuso do poder administrativo, no Brasil.

Preliminarmente, convém notar que o Brasil adota a unidade de jurisdição, do tipo anglo-saxão, onde a Administração é submetida ao direito nas mesmas condições dos cidadãos. A Administração é colocada em pé de igualdade quando em litígio com o administrado e a pendência é submetida à decisão do juiz comum. Contudo, "a autoridade judiciária fundar - se-á em razões juridicas, abstendo-se de apreciar o merecimento dos atos administrativos, sob o ponto-de-vista de sua conveniência ou oportunidade." Disso nos dá conta a Lei n 221, de 20-XI-1894, que instituiu a ação sumária especial destinada à anulação de atos de autoridades administrativas. Tratando-se de sistema administrativo do tipo anglo-saxão nada mais coerente do que a existência em nosso direito do mandado de segurança que surgiu, entre nós, através da Constituição de 1934. É êle espécie do gênero dos velhos mandados inglêses, "mandamus", "prohibition". "certiorari", dos quais hoje subsiste apenas o "habeas corpus." A influência francesa tem sido menos patente. Contudo, o advento da Lei $n^{\circ} 4.717$, de 29 de junho de 1965, nos trouxe a açio popular, em cujo texto podemos constatar a presença de todos aquêles elementos que vimos de enumerar no caso de recurso por excesso de poder. Êsses elementos não estão apenas implícitos mas suficientemente explícitos quando a lei estabelece:

“Art. 2\% São nulos os atos lesivos ao patrimônio das entidades mencionadas no artigo anterior nos casos de:

a) incompetência;

b) vício de forma;

c) ilegalidade do objeto;

d) inexistência dos motivos;

e) desvio de finalidade.

Parágrafo único. Para a conceituação dos casos de nulidade observar-se-ão as seguintes normas:

a) a incompetência fica caracterizada quando o ato năo se incluir nas atribuiçỏes legais do agente que a praticou;

b) o vicio da forma consiste na omissão ou na observância incompleta ou irregular de formalidades indispensáveis à existência ou seriedade do ato; 
c) a ilegalidade do objeto ocorre quando o resultado do ato importa em violação de lei, regulamento ou outro ato normativo;

d) a inexistência dos motivos se verifica quando a matéria de fato ou de direito, em que se fundamenta o ato, é materialmente inexistente ou juridicamente inadequada ao resultado obt do;

e) o desvio de finalidade se verifica quando o agente pratica $O$ ato visando a fim diverso daquele previsto, explicita ou implicitamente, na regra de competência."

\section{BIBLIOGRAFIA}

A. De LAUbadère - Manuol de Droit Administratif — Librairie de Droit et Jur:sprudence $-8^{*}$ ed:ção.

Lours Trotáns - Manuel de Droit Public et Administratif - Mesma editôra - $14^{*}$ edição.

JeAn Rivero - Droit Administratif - Librairie Dalloz - 3" edição.

Octavio de Barros Marques - Assistente Juridico do Ministério da Fazenda e ex-estag á o do govêrno franciss, na dircção-geral da Função Pủblica e na Escola Ñacional de Administração, em Paris. 